\title{
Author Correction: Type VI secretion system mutations reduced competitive fitness of classical Vibrio cholerae biotype
}

\author{
Benjamin Kostiuk, Francis J. Santoriello (1), Laura Diaz-Satizabal, Fabiana Bisaro, Kyung-Jo Lee, Anna N. Dhody (1), \\ Daniele Provenzano (D, Daniel Unterweger (i) \& Stefan Pukatzki (D)
}

Correction to: Nature Communications https://doi.org/10.1038/s41467-021-26847-y, published online 09 November 2021.

The original version of this Article contained errors in Fig. 4A, in which the country of isolation for the following Vibrio cholerae strains was incorrectly reported as Bangladesh: A46, A51, A111, A57, A61, A49, A103 and A279. The correct origins of the strains are, respectively: unknown, Egypt, unknown, India, India, unknown, unknown and Sweden. This has been corrected in both the PDF and HTML versions of the Article.

Published online: 11 February 2022

\begin{abstract}
(c) (i) Open Access This article is licensed under a Creative Commons Attribution 4.0 International License, which permits use, sharing, adaptation, distribution and reproduction in any medium or format, as long as you give appropriate credit to the original author(s) and the source, provide a link to the Creative Commons license, and indicate if changes were made. The images or other third party material in this article are included in the article's Creative Commons license, unless indicated otherwise in a credit line to the material. If material is not included in the article's Creative Commons license and your intended use is not permitted by statutory regulation or exceeds the permitted use, you will need to obtain permission directly from the copyright holder. To view a copy of this license, visit http://creativecommons.org/licenses/by/4.0/.
\end{abstract}

(C) The Author(s) 2022 